\title{
Oncogene JUN
}

National Cancer Institute

\section{Source}

National Cancer Institute. Oncogene JUN. NCI Thesaurus. Code C17555.

An oncogene from an avian sarcoma virus. The protein it encodes dimerizes with fos to form the transcription factor AP1. 